\title{
Effect of Zeolite Filler on the Thermal Degradation Kinetics of Polypropylene
}

\author{
H. Pehlivan, D. Balköse, S. Ülkü, F. Tıhmınlığlu \\ Chemical Engineering Department, Izmir Institute of Technology, Urla, Izmir, Turkey, 35430
}

Received 18 November 2004; accepted 15 June 2005

DOI 10.1002/app.23105

Published online in Wiley InterScience (www.interscience.wiley.com).

\begin{abstract}
In this study, the thermal degradation behavior of polypropylene (PP) and PP-zeolite composites was investigated. Clinoptilolite, a natural zeolitic tuff, was used as the filler material in composites. The effects of both pure clinoptilolite and silver-ion-exchanged clinoptilolite on the thermal degradation kinetics of the PP composites was studied with differential scanning calorimetry (DSC) and thermogravimetric analysis (TGA). Polymer degradation was evaluated with DSC at heating rates of 5,10 , and $20^{\circ} \mathrm{C} /$ min from room temperature to $500^{\circ} \mathrm{C}$. The silver concentration $(4.36,27.85$, and $183.8 \mathrm{mg}$ of $\mathrm{Ag} / \mathrm{g}$ of zeolite) was the selected parameter under consideration. From the DSC curves, we observed that the heat of degradation values of the composites containing 2-6\% silver-exchanged zeolite $(321-390 \mathrm{~kJ} / \mathrm{kg})$ were larger than that of the pure PP (258 $\mathrm{kJ} / \mathrm{kg}$ ). From the DSC results, we confirmed that the PPzeolite composites can be used at higher temperatures than
\end{abstract}

the pure PP polymer because of its higher thermal stability. The thermal decomposition activation energies of the composites were calculated with both the Kissinger and Ozawa models. The values predicted from these two equations were in close agreement. From the TGA curves, we found that zeolite addition into the PP matrix slowed the decomposition reaction; however, silver-exchanged zeolite addition into the matrix accelerated the reaction. The higher the silver concentration was, the lower were the thermal decomposition activation energies we obtained. As a result, PP was much more susceptible to thermal decomposition in the presence of silver-exchanged zeolite. (C) 2006 Wiley Periodicals, Inc. J Appl Polym Sci 101: 143-148, 2006

Key words: composites; degradation; kinetics (polym.); poly(propylene) (PP); zeolites

\section{INTRODUCTION}

Composites with desired properties can be achieved by the incorporation of fillers into a polymer matrix to suit various applications. Glass fibers, carbon fibers, and particulate fillers can be used as reinforcing materials. The primary advantages of polymeric composites are increases in stiffness, strength, and dimensional stability; reduced permeability to gases and liquids; and reduced cost. Polypropylene (PP) is among the most widely exploited thermoplastic polymers and is of increasing practical importance because of its good comprehensive use, light weight $(0.9 \mathrm{~g} / \mathrm{cc})$, chemical resistance, low cost, ease of processing, and good recycling properties. It has various applications, including food packaging, medical delivery systems, carpets, fibers, protective coatings, and applications in the automobile, electrical, and furniture industries,

Correspondence to: F. Tihmınlığlu (fundatihminlioglu@iyte. edu.tr).

Contract grant sponsor: Technical and Scientific Research Council of Turkey; contract grant number: MISAG 129.

Contract grant sponsor: Government Planning Institute; contract grant number: $120290 \mathrm{~K}$.

Journal of Applied Polymer Science, Vol. 101, 143-148 (2006) (C) 2006 Wiley Periodicals, Inc. depending on these properties. The properties of the composite materials are affected by the chemical properties of the components and the nature of the interaction between the phases. ${ }^{1}$

Different types of zeolite minerals, either natural (e.g., clinoptilolite, mordenite, chabazite) or synthetic (e.g., A type, $X$ type, $Y$ type), have been used as particulate fillers. ${ }^{2-4}$ All commercial zeolites owe their value to one of the following properties: ion exchange, adsorption, or catalysis. They have unusual crystalline structures that give them unique chemical properties. For instance, in $1 \mathrm{~g}$ of natural zeolite, channels can provide up to several hundreds of square meters of surface area on which chemical reactions can take place. Natural zeolite can also absorb up to $30 \%$ of its dry weight in gases, such as nitrogen or ammonia.

Studies have reported on the removal of lead, silver, and cadmium by clinoptilolite in the presence of competing concentrations of calcium, magnesium, and sodium via ion-exchange processes. ${ }^{5}$ Silver zeolites are of great importance because of their potential uses as germicidal, bactericidal, antifungal, and antiseptic components in different compositions. ${ }^{6-8}$ Silver salts appear to meet the requirements to as antiseptic agents. The modification of an inorganic compound by the addition of silver is attractive because silver 
grants protection from diseases originating from microorganisms.

Although an extensive amount of work has been done related to PP-based composite systems, most of the studies have been conducted with calcium carbonate, talc, or mica, ${ }^{9,10}$ and few studies have reported on zeolite as a filling material in the PP matrix. Our group previously worked on the preparation and characterization of PP-natural zeolite composites and also studied the effect of interfacial interactions on the properties of the composites. ${ }^{11,12}$

In this study, we examined the preparation and thermal characterization of silver-exchanged-zeolitefilled PP composites. The effects of the zeolite filler, both treated and untreated, and the silver concentration on the thermal degradation kinetics of PP were investigated.

\section{EXPERIMENTAL}

\section{Materials}

Isotactic PP in pellet form (MH 418, Petkim Petrochemicals Co.; Izmir, Turkey) was used for the matrix material, and natural zeolite, clinoptilolite, from Gördes region of Turkey was used as the filling material for the composite preparation. The natural zeolite was characterized earlier by Akdeniz. ${ }^{13}$ Poly(ethylene glycol) (PEG 4000; Aldrich; St. Louis, MO) was used as a surface modifier, and $\mathrm{AgNO}_{3}$ (Merck; Lindenplatz, Germany) was used as a source of silver for the preparation of the cationic form of the zeolite minerals. Dioctyl phthalate (DOP) was used as a plasticizer.

\section{Preparation of the materials}

The natural zeolite rocks were first hammered to break them down into smaller particles. These smaller particles were then wet-grinded with a Multifix ball mill with ethanol for $4 \mathrm{~h}$. After the grinding step, the slurry was dried at $110^{\circ} \mathrm{C}$ for a sufficient time to remove the ethyl alcohol from the mixture. The dried zeolites were then sieved in a $45-\mu \mathrm{m}$ sieve.

$\mathrm{AgNO}_{3}$ solutions with initial concentrations of 50, 500, and $5000 \mathrm{ppm}$ were used as the ion-exchange media. Zeolite minerals placed in $\mathrm{AgNO}_{3}$ solutions were kept at $25^{\circ} \mathrm{C}$ for $24 \mathrm{~h}$ in a water bath equipped with a shaker and a top cover to prevent the passage of light. In each set of experiments, the solid-to-liquid ratio was kept constant at $1 \mathrm{~g} / 100 \mathrm{~mL}$. Following the ion exchange process, we separated the solid and the liquid part of the slurry by filtering. The solid phase was washed twice to remove excessive silver ions. The samples were then dried in a vacuum oven at 400 mbar and $110^{\circ} \mathrm{C}$ for $3 \mathrm{~h}$.
TABLE I

Experimental Conditions of the Extrusion Process

\begin{tabular}{|c|c|c|c|c|c|c|c|c|}
\hline \multirow{2}{*}{$\begin{array}{c}\text { Screw } \\
\text { frequency } \\
\quad(\mathrm{Hz})\end{array}$} & \multirow{2}{*}{$\begin{array}{c}\text { Motor } \\
\text { voltage } \\
\text { (V) }\end{array}$} & \multirow{2}{*}{$\begin{array}{l}\text { Motor } \\
\text { current } \\
\text { (A) }\end{array}$} & \multicolumn{6}{|c|}{ Zone temperature $\left({ }^{\circ} \mathrm{C}\right)$} \\
\hline & & & 1 & 2 & 3 & 4 & 5 & 6 \\
\hline 20 & 38 & 4.5 & 200 & 220 & 220 & 220 & 220 & 22 \\
\hline
\end{tabular}

Surfaces of silver-exchanged and untreated zeolites were modified with PEG 4000 such that zeolites were mixed with a $50 \%$ aqueous ethanol solution containing 10\% modifier. The zeolite-to-solution ratio was $1: 0.3 \mathrm{w} / \mathrm{v}^{14}$

\section{Preparation of the PP-zeolite composite films}

Untreated and silver-exchanged zeolites were thoroughly mixed with PP pellets by physical means in the presence of DOP, which acted as a plasticizer. PP pellets, $45-\mu \mathrm{m}$ zeolite particles $(2,4$, and $6 \mathrm{wt} \%)$, and DOP $(10 \%$ total $\mathrm{w} / \mathrm{v})$ were mixed and conditioned at $85^{\circ} \mathrm{C}$ at $400 \mathrm{mbar}$ of pressure for $1 \mathrm{~h}$ just before the film-drawing process. The mixture of materials was then fed to the hopper of a miniextruder (Axon BX-18; Sweden). The experimental conditions, all of which were kept constant during the experimentation for the film-drawing process, are given in Table I. The extruder had a length/diameter ratio of 18 and a flat die with dimensions of $50 \times 1 \mathrm{~mm}$. A two-roll mill (Axon $2 \mathrm{R}-180$ ) with a roller frequency of $15 \mathrm{~Hz}$ was used to cast the film from the extruder. Tap water was circulated in polished rolls to solidify the polymer melt from the extruder.

\section{Characterization}

Inductively coupled plasma atomic emission spectrometry analyses

The extent of silver exchange onto the zeolites was determined through analysis of the remaining $\mathrm{Ag}^{+}$ concentration in the liquid phase with a Varian inductively coupled plasma atomic emission spectrometer (San Francisco, CA). First, a set of standard solutions with known silver concentrations was prepared. With these standards, a calibration curve was constructed by the instrument at a wavelength of 328.068 . The concentrations of the silver-ion-exchanged samples were then detected according to that calibration curve.

\section{Thermal analyses}

Thermal analyses of PP and the PP-zeolite composites were conducted with a Shimadzu differential scanning calorimeter (DSC 50; Kyoto, Japan) and a Shimadzu thermal gravimetric analyzer (TGA 51). The experiments were carried out from room temperature 
to $500^{\circ} \mathrm{C}$ for the differential scanning calorimetry (DSC) analyses and up to $1000^{\circ} \mathrm{C}$ for the thermogravimetric analyses (TGAs) at heating rates ( $\beta^{\prime}$ s) of 5,10 , and $20^{\circ} \mathrm{C} / \mathrm{min}$. The analyses were performed in a dry nitrogen atmosphere. The $\mathrm{N}_{2}$ flow rate was $40 \mathrm{~mL} /$ min and was kept constant throughout the experiments.

\section{RESULTS AND DISCUSSION}

\section{$\mathrm{Ag}^{+}$exchange to zeolites}

The amounts of $\mathrm{Ag}^{+}$loaded per gram of zeolite for initial $\mathrm{AgNO}_{3}$ concentrations of 50,500, and $5000 \mathrm{ppm}$ were determined as $4.36,27.85$, and $183.78 \mathrm{mg} / \mathrm{g}$ of zeolite, respectively, through analysis of the liquid phase. The maximum amount of silver taken by Gördes 1 zeolite (183.78 $\mathrm{mg}$ of $\mathrm{Ag}^{+} / \mathrm{g}$ of zeolite) in this study was comparable with the silver uptake in different monocationic forms of clinoptilolite. The original clinoptilolite and the $\mathrm{NH}_{4}, \mathrm{~K}$, and $\mathrm{Na}$ forms of clinoptilolite were determined to take 74.0, 84.3, 86.6, and $120.7 \mathrm{mg}$ of $\mathrm{Ag}^{+} / \mathrm{g}$ of clinoptilolite, respectively. The good exchangeability of silver ions into zeolite could be explained by the high polarizability of the silver ions. The electrostatic charge of the zeolite lattice is capable of polarizing silver ions so that they become dipoles directing their positively charged end to the lattice. ${ }^{15}$

\section{Thermal analyses}

In this study, DSC and TGA were used for the thermal characterizations of the PP, natural zeolite, and PPsilver zeolite composite films. The melting, crystallization, and degradation behaviors and the kinetic analysis of the composites were investigated.

\section{DSC studies}

Figure 1 shows the DSC curves of the composite films containing $4 \mathrm{wt} \%$ zeolite with three different silver concentrations, $4.36,27.85,183,78 \mathrm{mg}$ of $\mathrm{Ag}^{+} / \mathrm{g}$ of zeolite, at a $\beta$ of $10^{\circ} \mathrm{C} / \mathrm{min}$. As shown in Figure 1, the melting and degradation temperatures were in the range $161.5-162.7$ and $459.8-462.8^{\circ} \mathrm{C}$, respectively. The DSC curves of the different composite samples showed very similar results. Thus, all the samples' melting and degradation peak temperatures were between 161 and 165 and 459 and $466^{\circ} \mathrm{C}$, respectively. This showed that the silver concentration and zeolite loading did not significantly affect the peak temperatures of melting and degradation. The heat of fusion $\left(\Delta H_{f}\right)$ and heat of degradation $\left(\Delta H_{d}\right)$ were determined from the melting and degradation endotherm areas, respectively. The $\Delta H_{f}$ and $\Delta H_{d}$ values showed an increasing trend with increasing zeolite loading and

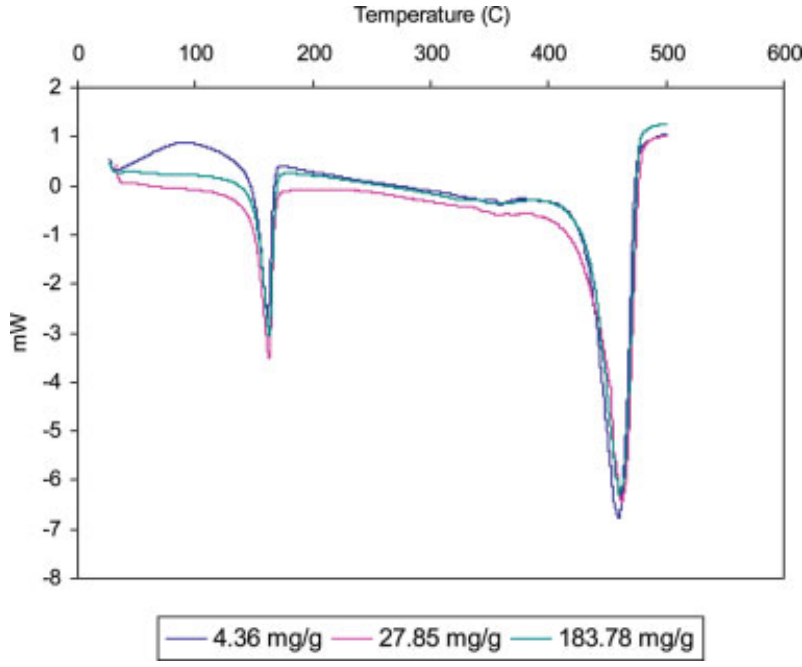

Figure 1 DSC curves of the composites containing 4 wt \% zeolite treated with three different concentrations of silver. [Color figure can be viewed in the online issue, which is available at www.interscience.wiley.com.]

silver concentration except for the case of samples with $183.78 \mathrm{mg}$ of $\mathrm{Ag}^{+} / \mathrm{g}$ of zeolite. The $\Delta H_{f}$ values were in the range of $59.6-84 \mathrm{~kJ} / \mathrm{kg}$ for the $0-6 \mathrm{wt} \%$ silver-zeolite-containing composites. Özmıhçı et al. ${ }^{2}$ previously found $\Delta H_{f}$ values in the range 63.8-87 $\mathrm{kJ} / \mathrm{kg}$ for $0-6 \mathrm{wt} \%$ untreated-zeolite-containing composites. For a $\beta$ of $10^{\circ} \mathrm{C} / \mathrm{min}$, quantitative information about peak temperatures for melting and degradation, enthalpy of fusion $\left(\Delta H_{f}\right)$, and enthalpy of degradation values $\left(\Delta H_{d}\right)$ and the percentage crystallinity values are tabulated in Table II. The percentage crystallinity of the films was determined with eq. (1):

$$
\begin{aligned}
& \text { Crystallinity }(\%) \\
& \qquad=\frac{\Delta H_{f} \text { of the sample }}{\Delta H_{f} \text { of the } 100 \% \text { crystalline sample }} \times 100
\end{aligned}
$$

The $\Delta H_{f}$ value for $100 \%$ crystalline isotactic PP was taken as $209 \mathrm{~kJ} / \mathrm{kg}^{14}$ This value was used to determine the percentage crystallinity of the composites. Pure PP film was $28.5 \%$ crystalline; the composites had higher crystallinities in the range $33-40 \%$. The higher the zeolite content was, the higher the crystallinity values were for the composites, as shown in Table II. We concluded that the zeolite particles acted as a nucleation agent in the PP matrix.

A higher enthalpy change $(314.6-390.2 \mathrm{~kJ} / \mathrm{kg}$ ) was observed during the degradation of the films with silver-loaded zeolite than during that of the control films $(258.2 \mathrm{~kJ} / \mathrm{kg})$. PP degrades by random scission, and lower molecular weight products are formed by this process. Although the polymerization of $\mathrm{PP}$ is an exothermic process having an energy of $2040 \mathrm{~kJ} / \mathrm{kg}^{16}$ the degradation is endothermic. The higher the num- 
TABLE II

DSC Analysis Results for the Composites

\begin{tabular}{cccccc}
\hline $\begin{array}{c}\text { Zeolite } \\
\text { loading } \\
(\text { wt \%) }\end{array}$ & $\begin{array}{c}\mathrm{Ag}^{+} \\
\text {concentration } \\
(\mathrm{mg} / \mathrm{g} \text { of zeolite })\end{array}$ & $\begin{array}{c}\text { Melting peak } \\
\text { temperature } \\
\left({ }^{\circ} \mathrm{C}\right)\end{array}$ & $\begin{array}{c}\text { Degradation peak } \\
\text { temperature }\left({ }^{\circ} \mathrm{C}\right)\end{array}$ & $\begin{array}{c}\Delta H_{f} \\
(\mathrm{~kJ} / \mathrm{kg})\end{array}$ & $\begin{array}{c}\Delta H_{d} \\
(\mathrm{~kJ} / \mathrm{kg})\end{array}$ \\
\hline 0 & 0 & 165.0 & 459.8 & 59.6 & 258.2 \\
2 & 4.36 & 161.0 & 464.2 & 58.4 & 321.8 \\
4 & 4.36 & 161.5 & 459.8 & 70.0 & 352.1 \\
6 & 4.36 & 165.6 & 459.3 & 79.2 & 363.5 \\
2 & 27.85 & 158.4 & 464.1 & 72.7 & 315.8 \\
4 & 27.85 & 162.7 & 462.8 & 79.3 & 360.5 \\
6 & 27.85 & 165.7 & 465.7 & 83.8 & 319.4 \\
2 & 183.8 & 162.7 & 466.5 & 78.2 & 37.5 \\
4 & 183.8 & 162.7 & 459.9 & 69.7 & 37.8 \\
6 & 183.8 & 162.6 & 462.6 & 81.5 & 335.3 \\
\hline
\end{tabular}

ber of the bonds broken by degradation is, the higher the amount of heat will be absorbed. Thus, the presence of silver-loaded zeolite caused the formation of lower molecular weight degradation products than those of the control films. Kim et al. ${ }^{17}$ studied the catalytic degradation of PP with clinoptilolite zeolites and found that clinoptilolite was an efficient catalyst for the conversion of PP to lower molecular weight products. According to the their findings, low-carbonnumber product distribution during degradation were determined in the ranges $4-12$ with a zeolite catalyst and 4-26 without zeolite (thermal degradation). Our results show that this range was 5-7 for silver-exchanged-zeolite-loaded composites and 8 for pure PP, which again showed that lower molecular weight products were obtained in the silver-loaded zeolite composites. This was consistent with the $\Delta H_{d}$ values.

The thermal degradation activation energy $\left(E_{a}\right)$ values of the composites were determined with the Kiss-

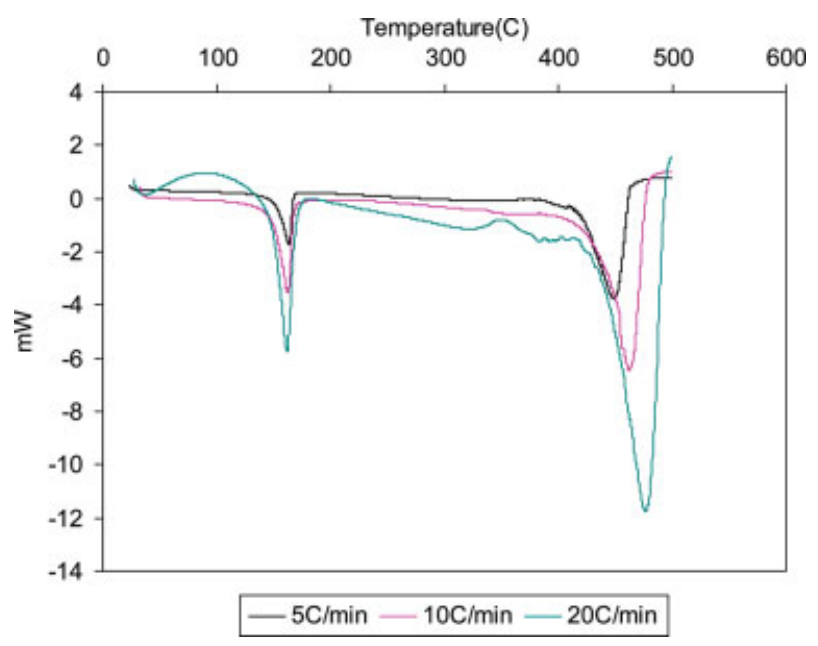

Figure 2 DSC curves of the 4 wt \% zeolite composites (4.36 $\mathrm{mg}$ of $\mathrm{Ag}^{+} / \mathrm{g}$ of zeolite). [Color figure can be viewed in the online issue, which is available at www.interscience.wiley. com.] inger and Ozawa methods..$^{3,4,14,18}$ According to the Kissinger method, $E_{a}$ is determined from the slope of a $\log \beta$ versus $1 / T_{d}$ plot, corresponding to $-E_{a} / R$ with eq. (2):

$$
\frac{d(\log \beta)}{d\left(1 / T_{d}\right)}=-\frac{E_{a}}{R}
$$

where $\beta$ is the heating rate $\left({ }^{\circ} \mathrm{C} / \mathrm{min}\right), T_{d}$ is the peak maximum for degradation temperature, $E_{a}$ is the activation energy, and $R$ is the gas constant. The thermal decomposition temperature was measured from the DSC thermograms of the composites for various $\beta^{\prime}$ s. The DSC thermograms of the $4 \mathrm{wt} \%$ zeolite sample loaded with $4.36 \mathrm{mg}$ of $\mathrm{Ag}^{+} / \mathrm{g}$ of zeolite taken at three different $\beta^{\prime}$ s are shown in Figure 2. Figure 3 illustrates the plot of $\ln \beta$ versus $1 / T_{d}$ for the same composites. From the slope of this plot, $E_{a}$ was calculated to be 170 $\mathrm{kJ} / \mathrm{mol}$.

The DSC curves were also analyzed according to the Ozawa method with Shimadzu 50 kinetic analysis software. The quantitative information obtained from

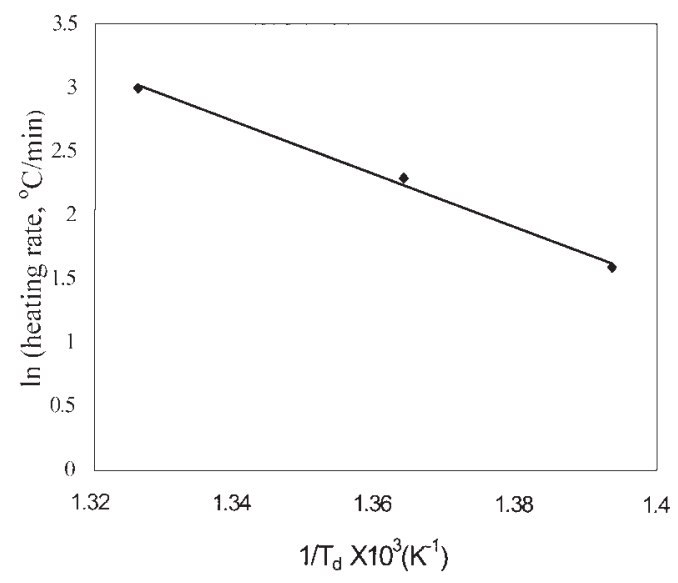

Figure 3 Kissinger plot of the $4 \mathrm{wt} \%$ zeolite composite film treated with $4.36 \mathrm{mg}$ of $\mathrm{Ag}^{+} / \mathrm{g}$ of zeolite. 
TABLE III

Degradation Kinetic Constants for the 4 wt \% ZeoliteLoaded Composite Films from DSC Analysis

\begin{tabular}{cccccc}
\hline & $\begin{array}{c}\text { Kissinger } \\
\text { method }\end{array}$ & & \multicolumn{3}{c}{ Ozawa method } \\
\cline { 5 - 6 } \cline { 5 - 6 } $\begin{array}{c}\mathrm{Ag}^{+} \\
\begin{array}{c}\text { concentration } \\
(\mathrm{mg} / \mathrm{g} \text { of } \\
\text { zeolite })\end{array}\end{array}$ & & & & & \multicolumn{3}{c}{$\begin{array}{c}k \times 10^{2} \\
\text { at }\end{array}$} \\
& & & & & \\
$4(\mathrm{~kJ} / \mathrm{mol})$ & & $E(\mathrm{~kJ} / \mathrm{mol})$ & $A\left(\mathrm{~min}^{-1}\right)$ & $450^{\circ} \mathrm{C}$ \\
\hline 0 & 190 & & 187.0 & $1.08 \times 10^{13}$ & 33.7 \\
4.36 & 170 & & 168 & $4.09 \times 10^{11}$ & 29.7 \\
27.85 & 221 & & 226 & $6.2 \times 10^{15}$ & 29.1 \\
183.78 & 215 & & 214 & $8.68 \times 10^{14}$ & 29.9 \\
\hline
\end{tabular}

the kinetic analysis of the samples performed with both the Ozawa and the Kissinger equations are tabulated in Table III. The values predicted from these two equations were in good agreement.

Because thermal decomposition occurred around $450^{\circ} \mathrm{C}$, the reaction constant $k$ was calculated at $450^{\circ} \mathrm{C}$ with the Arrhenius equation

$$
k=A \exp \left(-\mathrm{E}_{a} / R T\right)
$$

where $E_{a}$ is the activation energy $(\mathrm{kJ} / \mathrm{mol}), A$ is the frequency factor $\left(\mathrm{min}^{-1}\right), R$ is the gas constant, and $T$ is the temperature $(\mathrm{K})$

$k$ was not significantly affected by the increasing silver concentration, and slight increases occurred, but zeolite addition decreased the decomposition rate.

\section{TGA studies}

The TGA thermograms of the 4 wt \% zeolite sample with respect to silver concentration are shown in Fig-

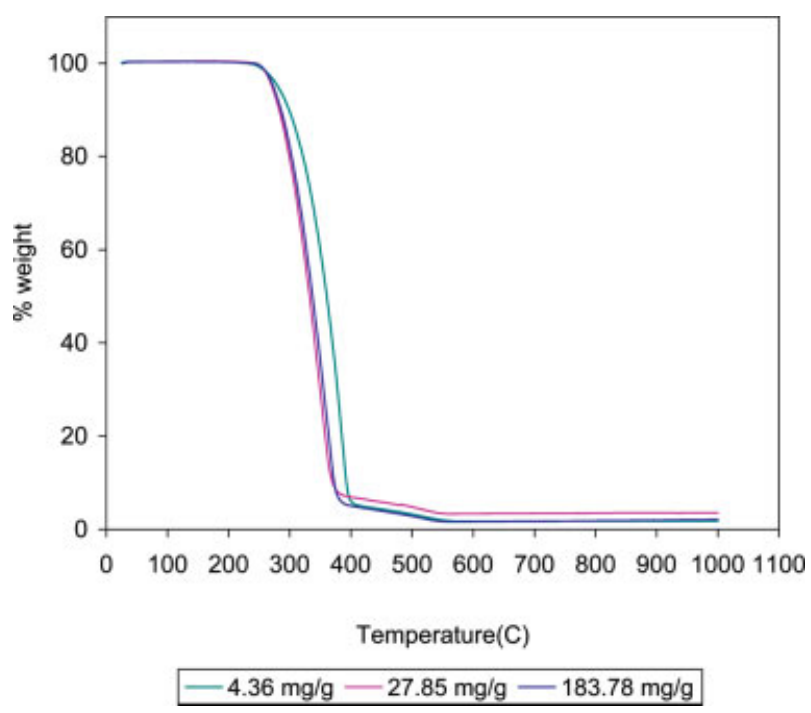

Figure 4 TGA thermograms of the 4 wt \% zeolite sample with respect to silver concentration at a $\beta$ of $10^{\circ} \mathrm{C} / \mathrm{min}$. [Color figure can be viewed in the online issue, which is available at www.interscience.wiley.com.]
TABLE IV

Degradation Temperatures for 4 wt \% Zeolite-Loaded Composites as a Function of Silver Concentration

\begin{tabular}{cccc}
\hline $\begin{array}{c}\text { Amount of } \mathrm{Ag}^{+} \\
\text {exchanged on the } \\
\text { composites } \\
\left(\mathrm{mg} \text { of } \mathrm{Ag}^{+} / \mathrm{g} \text { of zeolite) }\right.\end{array}$ & $\begin{array}{c}\text { Onset of } \\
\text { degradation } \\
\left({ }^{\circ} \mathrm{C}\right)\end{array}$ & $\begin{array}{c}\text { Termination } \\
\text { of } \\
\left({ }^{\circ} \mathrm{C}\right)\end{array}$ & $\begin{array}{c}\text { Weight } \\
\text { degradation } \\
(\text { wt \%) }\end{array}$ \\
\hline 4.36 & 212 & 557 & 98.6 \\
27.85 & 224 & 554 & 96.9 \\
183.78 & 226 & 552 & 98.3 \\
\hline
\end{tabular}

ure 4 at a $\beta$ of $10^{\circ} \mathrm{C} / \mathrm{min}$. TGAs of the three different samples showed very similar results. With increasing silver concentration, the onset of degradation shifted to slightly higher values, as shown in Table IV. On the average, degradation started around $220^{\circ} \mathrm{C}$ and terminated at about $550^{\circ} \mathrm{C}$. The TGA curves of the samples containing 27.85 and $183.78 \mathrm{mg}$ of $\mathrm{Ag}^{+} / \mathrm{g}$ almost overlapped each other, whereas the sample containing 4.36 $\mathrm{mg}$ of $\mathrm{Ag}^{+} / \mathrm{g}$ showed a slower decrease than the other two samples. The weight losses of the samples containing $4.36,27.85$, and $183.78 \mathrm{mg}$ of $\mathrm{Ag}^{+} / \mathrm{g}$ came out to be $98.6,96.9$, and $98.3 \%$, respectively. Although all the samples were supposed to contain $4 \mathrm{wt} \%$ zeolite, the TGA results did not agree with this, which indicated that the zeolite distribution along the composite films was not uniform. Table IV presents the onset and termination of degradation temperatures for $4 \mathrm{wt} \%$ zeolite-loaded composites as a function of silver concentration.

The kinetic analyses with TGA were performed with $\beta^{\prime}$ s of 5,10 , and $20^{\circ} \mathrm{C} / \mathrm{min}$ for the $4 \mathrm{wt} \%$ zeolite samples. Figure 5 shows the TGA curves of the $4 \mathrm{wt} \%$

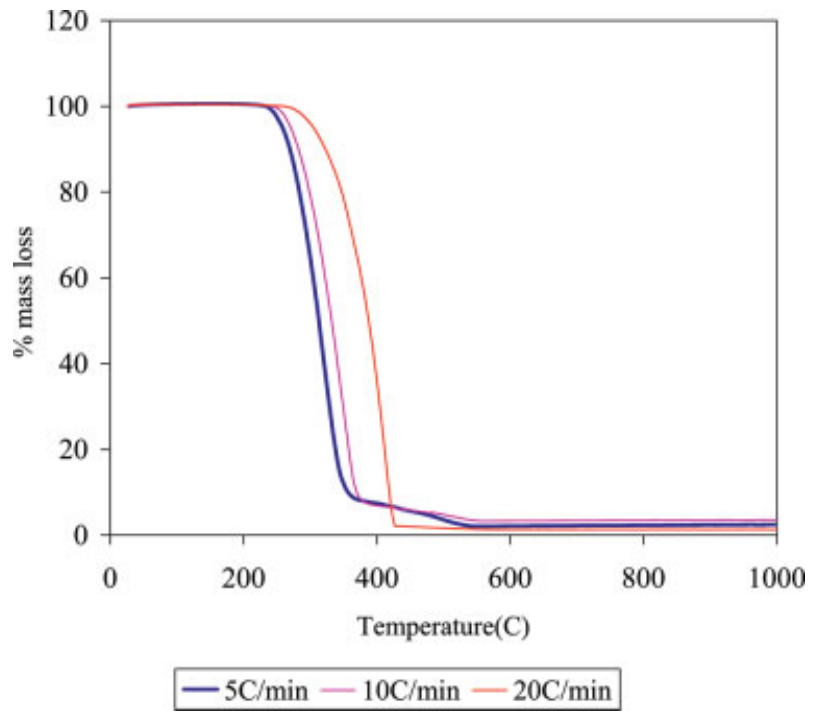

Figure 5 TGA curves of the 4 wt \% zeolite composites (27.85 $\mathrm{mg}$ of $\mathrm{Ag}^{+} / \mathrm{g}$ of zeolite) at various $\beta^{\prime}$ s. [Color figure can be viewed in the online issue, which is available at www.interscience.wiley.com.] 
TABLE V

Degradation Kinetic Constants for the 4 wt \% Zeolite-Containing Composite Films Obtained from DSC and TGA

\begin{tabular}{|c|c|c|c|c|c|c|c|c|}
\hline \multirow{2}{*}{$\begin{array}{l}\mathrm{Ag}^{+} \\
\text {concentration } \\
(\mathrm{mg} / \mathrm{g})\end{array}$} & \multirow[b]{2}{*}{$\begin{array}{c}\text { Zeolite } \\
(\%)\end{array}$} & \multicolumn{3}{|c|}{ DSC } & \multicolumn{4}{|c|}{ TGA } \\
\hline & & $E(\mathrm{~kJ} / \mathrm{mol})$ & $A$ & $\begin{array}{c}k\left(\min ^{-1}\right) \\
\text { at } 450^{\circ} \mathrm{C}\end{array}$ & $E(\mathrm{~kJ} / \mathrm{mol})$ & $L$ & $A$ & $\begin{array}{c}k\left(\min ^{-1}\right) \\
\text { at } 450^{\circ} \mathrm{C}\end{array}$ \\
\hline 0 & 0 & 181.1 & $3.5 \times 10^{12}$ & 0.285 & 56.1 & 5 & $4.79 \times 10^{3}$ & 0.42 \\
\hline 4.36 & 4 & 168.0 & $4.09 \times 10^{11}$ & 0.297 & 96.5 & 5 & $9.98 \times 10^{6}$ & 1.06 \\
\hline 27.85 & 4 & 226.0 & $6.2 \times 10^{15}$ & 0.291 & 56.5 & 4 & $7.75 \times 10^{3}$ & 0.64 \\
\hline 183.78 & 4 & 214.0 & $8.68 \times 10^{14}$ & 0.299 & 64.6 & 5 & $2.78 \times 10^{4}$ & 0.59 \\
\hline
\end{tabular}

zeolite samples containing $27.85 \mathrm{mg}$ of $\mathrm{Ag}^{+} / \mathrm{g}$. As $\beta$ increased, the thermograms shifted toward the right, and the degradation temperature increased. Kinetic analyses of these composites were performed with the Shimadzu 51 TGA kinetic analysis software within the temperature range $250-550^{\circ} \mathrm{C}$. An Ozawa plot showed $\log \beta$ versus $1 / T$ at constant reaction percentage for different weight losses. From the slope of the lines, $E_{a}$ was calculated for different weight losses and averaged. The kinetic energies and the related parameters obtained for the $4 \mathrm{wt} \%$ zeolite-containing samples are shown in Table V. In Table V, $L$ is the order for the degradation reaction. $L$ is a measure of the minimum degree of polymerization of the volatile degradation products. If the degree of polymerization of the degraded polymer is lower than a critical $L$ value, it is volatile. $L$ was around 5 for PP. ${ }^{2}$

The reaction rate constant for the degradation reaction was determined with an Arrhenius equation at $450^{\circ} \mathrm{C}$ and is given in Table V. Zeolite addition into the PP matrix slowed the decomposition reaction; however, the $E_{a}$ values of the samples with a specified zeolite loading decreased with increasing silver concentration. This showed that PP was much more susceptible to thermal decomposition in the presence of silver-exchanged zeolite compared to pure PP.

The $E_{a}$ and $A$ values found for the degradation of PP by DSC and TGA (Table V) were very different from each other, which indicated that the heat absorbed and evolved gasses were not proportional.

\section{CONCLUSIONS}

In this study, natural zeolite and PP-silver-exchanged natural zeolite composites were prepared via an extrusion technique, and the effect of zeolite loading and silver concentration were investigated on the thermal degradation kinetics of the composites by DSC and TGA. The DSC studies showed that the zeolite increased the crystallinity of the structure by acting as a nucleating agent in the PP crystallization. For the PPsilver-exchanged zeolite composites, increases in the heat of melting and degradation values were more significant, especially with increasing silver concentration. The $\Delta H_{d}$ values of the composites containing
2-6\% silver-exchanged zeolite $(321-390 \mathrm{~kJ} / \mathrm{kg}$ ) were larger compared than those of the pure PP free of silver and zeolite $(258 \mathrm{~kJ} / \mathrm{kg})$. At low silver concentrations, the zeolite behaved as a decelerating agent in PP degradation; however, at higher silver concentrations, the composites degraded faster than pure PP.

TGA showed that zeolite addition into the PP matrix slowed the decomposition reaction; however, silver-exchanged zeolite addition into the matrix accelerated the reaction. The higher the silver concentration was, the lower the $E_{a}{ }^{\prime}$ s were. As a result, PP was much more susceptible to thermal decomposition in the presence of silver-exchanged zeolite than in the presence of the pure zeolite.

The authors thank Petkim Petrochemicals Co. for supplying the PP samples.

\section{References}

1. Moore, E. P. Polypropylene Handbook: Polymerization, Characterization, Properties, Processing, Applications; Hanser/ Gardner: Cincinnati, OH, 1996.

2. Özmıhçı, F.; Balköse, D.; Ülkü, S. J Appl Polym Sci 2001, 82, 2913.

3. Fernandes, V. J.; Araujo, A. S.; Medeiros, R. A.; Matos, J. R.; Mercuri, L. P.; Silva, A. O.; Melo, D. M. A. J Therm Anal Calorim 1999, 56, 1279.

4. Cho, Y.; Shim, M.; Kim, S. Mater Chem Phys 1998, 52, 94.

5. Semmens, M. J.; Martin, W. AIChE Symp Ser 1979, 76, 197.

6. Hagiwara, Z.; Hoshiro, S.; Nohara, S.; Tagawa, K. U.S. Pat. 4, 911, 898 (1990).

7. Kawahara, K.; Tsuruda, K.; Morishita, M.; Uchida, M. Dent Mater 2000, 16, 452.

8. Klasen, H. J. Burns 2000, 26, 207.

9. Akovalı G.; Akman, M. A. Polym Int 1997, 42, 195.

10. Maiti, S. N.; Sharma, K. K. J Mater Sci 1992, 27, 4605.

11. Pehlivan, H.; Balköse, D.; Ülkü S.; Tihmınlıglu, F. Compos Sci Technol, to appear.

12. Metin, D.; Tihmınlıoglu, F.; Balköse, D.; Ülkü, S. Compos A 2004, 35, 23.

13. Akdeniz, Y. M.S. Thesis, İzmir Institute of Technology, 1999.

14. Pehlivan, H. M.S. Thesis, İzmir Institute of Technology, 2001.

15. Czaran, E.; Papp, J.; Agnes, M. K.; Domokos, E. Acta Chim Hung 1989, 126.

16. Rodriquez, F. Principles of Polymer Systems, 4th ed.; Taylor \& Francis: Washington, DC, 1996.

17. Kim, J. R.; Kim, Y. A.; Yoon, J. H.; Park, D. W.; Woo, H. C. Polym Degrad Stab 2002, 75, 287.

18. Horrocks, A. R.; D’Souza, J. A. J Appl Polym Sci 1991, 42, 243. 